\title{
Doctors call for change in union tactics in health care strikes
}

\author{
n Cite as: CMAJ 2018 October 22;190:E1264-5. doi: 10.1503/cmaj.109-5666
}

Posted on cmajnews.com on Oct. 2, 2018.

$\mathrm{T}$ wo bitter strikes at health care clinics in Ontario this summer have left doctors and patients questioning the tactics of union members on picket lines, which they say have put people's health at risk.

In Thunder Bay, medical aides and administrators from the Unifor union at the Port Arthur Health Centre went on strike in April, demanding better pay and working conditions. The strike ended only after the union erected a temporary fence around the clinic in August, effectively shutting it down for three days.

At the Owen Sound Family Health Team, a strike by nurses, administrators and custodial staff represented by OPSEU (Ontario Public Service Employees
Union) began in May and ended in September. All striking employees opted for enhanced severance payments rather than return to work.

In each strike, both sides alleged insults, intimidation and violence. The clinics allege that union tactics put patients at risk. "For three days, patients were not allowed to access the clinic, in some cases for important blood work, medical imaging or to pick up prescriptions," said John Marrello, CEO of Port Arthur.

Karen Smith Turner, executive director of the Owen Sound clinic, said she was involved in "situation after situation" in which patients were subjected to harassment while crossing the picket line. "What they endured was awful and pathetic,"

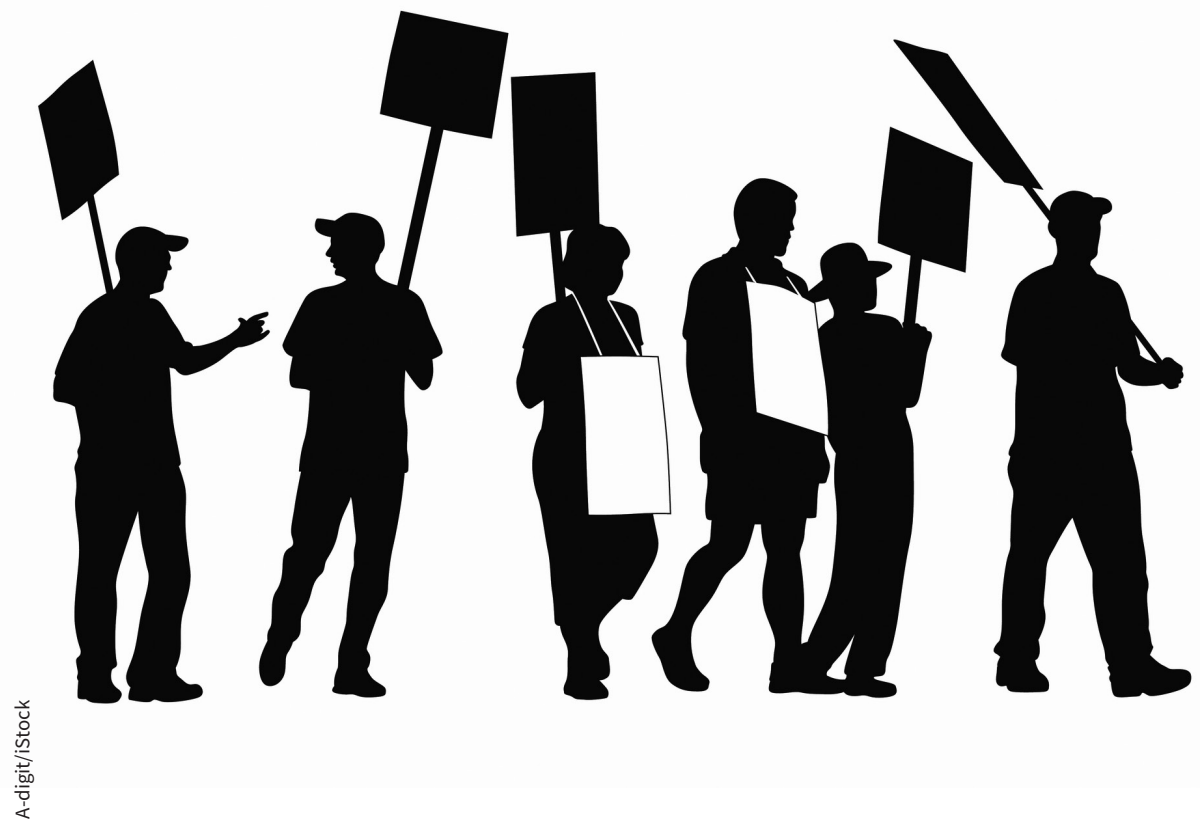

Should there be different rules for a picket line at a health care facility than at a traditional industrial employer? she said. "We teach kids not to bully, and this is an example of bullying."

One patient in Owen Sound, a military veteran with posttraumatic stress disorder, wrote a letter claiming he was temporarily prevented from crossing the picket line and subjected to verbal abuse. Another patient claimed that picketers struck her car, which resulted in more than $\$ 4000$ of damage.

Both Marrello and Smith Turner said they feel there should be different rules for a picket line at a health care facility than at a traditional industrial employer. "We're not making products here; this is not material trying to be delivered," said Smith Turner. "These are people requiring care."

Marrello said many patients were told by the striking workers to go elsewhere for care, but that is not always easy. Finding a family doctor can be difficult at the best of times, and the Thunder Bay clinic includes several specialists whom patients wait months to see. "Shutting that down shouldn't be an option," he said.

Unifor did not respond to requests for comment. Warren Thomas, president of OPSEU, said that although the Owen Sound strike became bitter, there was no violence on the union's side. He said because Owen Sound is a small town where there haven't been many strikes, some members of the public may be unfamiliar with how they work, so they were irritated at being temporarily held back when crossing the line, while workers explained the reason for the strike. "That's how picket lines work. You hold people for a short time," he said.

Thomas said the strikers, most of whom were women, suffered verbal 
abuse and misogynistic comments from doctors at the clinic and some patients. "The doctors should be ashamed for treating people that way," he said.

One member of the union, who had travelled from head office to support the strikers, had her foot run over by a patient's car and may require surgery. After the incident, the strikers reinforced the picket line with temporary barri- cades and a spiked board to protect themselves, said Thomas. "The strike was legal, and the activity on the line was legal. No one on the line was charged," he said.

Larry Savage, a professor of labour studies at Brock University, said that blockades are not a common tactic at strikes in Canada, and are generally a last resort. "If they thought they were effec- tive, the union wouldn't wait until so long into the dispute," he said.

Long, bitter strikes can lead people to take drastic action, he added. "The length and acrimony can push people to do things they normally wouldn't do," he said. "And that's true on both the union and management side."

Brian Owens, St. Stephens, NB 